\title{
Joint actions with large partners and small-firm ambidexterity in asymmetric alliances: The mediating role of relational identification
}

\author{
Yanan Feng \\ Nottingham University Business School, The University of Nottingham \\ Da Teng \\ School of Strategy and Leadership, Coventry University \\ Bin Hao \\ School of Business, East China University of Science and Technology
}

\begin{abstract}
This study investigates the role of relational identification in the relation between joint actions and small-firm ambidexterity in asymmetric alliances. Using survey data on Chinese high-technology firms, we find that joint problem-solving and joint sensemaking are both positively associated with small firm's relational identification. We also find a positive relationship between small firm's relational identification and knowledge exploration and exploitation. More importantly, we show that relational identification mediates the relationships between joint actions (i.e., joint problem-solving and joint sensemaking) and small-firm ambidexterity, except for the relationship between joint sensemaking and small-firm knowledge exploitation. This study advances our understanding of the association between joint actions and ambidexterity by providing a social identification explanation.
\end{abstract}

Key words: asymmetric alliance, exploration, exploitation, relational identification, small firm.

\section{INTRODUCTION}

Strategic alliances, which are "voluntary arrangements between firms involving exchange, sharing, or codevelopment of products, technologies, or services' (Gulati, 1998), have been a core area of research (e.g., Wang, Chen and Fang, 2018). Recently, scholars have increasingly referred to a particular type of alliance - an asymmetric alliance between a small firm and a large firm that is 
characterized by a significant status difference or dependence asymmetry (Kalaignanam, Shankar, and Varadarajan, 2007; Kamuriwo, Baden-Fuller and Zhang, 2017; Skarp and Gadde, 2008; Yang, Zheng, and Zhao, 2014). It is suggested that small firms promote learning and technology improvement by engaging in interrelated activities with their large alliance partners (e.g., Benitez, Castillo, Llorens, and Braojos, 2018; Gawer and Phillips, 2013; Hagedoorn, Lokshin, and Malo, 2018; Kauppila, 2010; Perrons, 2009). The rationale is that large, established firms have more experience and stronger research and development (R\&D) capabilities than small firms, and that joint actions can help enhance small firm's capabilities in conducting knowledge searching (Stuart, 2000). Joint action, defined as the degree of interpenetration of organisational boundaries (Heide and John, 1990), represents in-depth cooperation between alliance partners on certain activities that are important for improving the performance of both parties (Flatten, Greve, and Brettel, 2011). Different types of joint actions, such as joint problem-solving and joint sensemaking, increase the opportunity to engage in a partner's internal processes and operations (Fugate, Stank, and Mentzer, 2009; Hult, Ketchen, and Slater, 2004), which entails the potential for a small firm to conduct exploratory and exploitative learning (e.g., Levinthal and March, 1993; Rothaermel and Deeds, 2004; Volery, Mueller and von Siemens, 2015). Nevertheless, small firms conducting joint actions with large alliance partners may be exposed to the risk of knowledge misappropriation (Katila, Rosenberg, and Eisenhardt, 2008; Rothaermel, 2001), thereby reducing their motivation for knowledge exploration and exploitation. The simultaneous presence of learning-enhancing and learning-damaging effects makes it unclear whether joint actions promote ambidexterity. Then, how do joint actions with large partner firms affect small-firm knowledge exploration and exploitation in asymmetric alliances?

In this study, we draw on theories of identification to disentangle the mechanism through which joint actions affect small-firm ambidexterity in asymmetric alliances. Since the mainstream literature has suggested that identification between organisations has implications for organisational learning and innovation (Corsten, Gruen and Peyinghaus, 2011; Dyer and Nobeoka, 2000), we posit that a small firm's willingness to conduct knowledge exploration and exploitation may be determined by its identification with the relationship with its large partner (Dyer, 1997). Exploration refers to the development of new products that depart from existing technological trajectories, and exploitation 
concerns incremental improvements to existing products using existing technologies (Levinthal and March, 1993). We introduce the term relational identification and examine its mediating effect on the relationship between joint actions and small-firm ambidexterity. As our focus here is alliance collaboration, we define relational identification as the extent to which an alliance firm defines itself in terms of a given collaborative relationship (Slush and Ashforth, 2007; Corsten et al., 2011). As a concept derived from social identification, relational identification between organisations can be helpful in explaining an organisation's motivation to conduct learning behaviors in a given alliance relationship (Corsten et al., 2011; Ireland and Webb, 2007; McKelvie, Brattström, and Wennberg, 2017). This contrasts with a knowledge-based explanation of ambidexterity, which only highlights distant and local knowledge searches, while neglecting the motivational forces behind them. Moreover, a small firm's decisions are made based on its social judgments and evaluations as it is a socio-cognitive entity (Arranz, Arroyabe, and Arroyabe, 2016; Mishina, Block, and Mannor, 2012). Its decision to invest money or energy in conducting knowledge exploration and exploitation may thus be dependent on its identification with the relationship with its large partner. From this perspective, a focus on identification in partnerships complements the traditional wisdom of leveraging a knowledge base for learning, which may help reveal the mechanism of small-firm ambidexterity in an asymmetric alliance.

Following existing studies (McEvily and Marcus, 2005; Revilla and Villena, 2012), we focus on two types of joint actions: joint sensemaking and joint problem-solving. Joint sensemaking refers to the mechanism by which the partners share information and develop a common understanding of strategic issues for the collaborative relationship (Revilla and Villena, 2012). Joint problem-solving is defined as a complex and time-consuming process between partners that involves problem identification, solution design and implementation, and the solution-derived outcomes (e.g., Skarp and Gadde, 2008). We strive to build a model in which joint problem-solving and joint sensemaking with the large partner directly, or through the strengthening of relational identification, stimulate a small firm's knowledge exploration and exploitation. We test our theory using survey data on 205 high-technology firms in China, and the results provide support for most of our conjectures. 


\section{THEORY AND HYPOTHESES}

\section{Small-firm learning through joint actions with large alliance partner}

Studies on alliance partnership have increasingly noticed the collaboration between small firms and large firms (Dutta and Hora, 2017; Knoben and Bakker, 2019; Shaw, Wilson and Pret, 2017; Subramanian, Bo and Kah-Hin, 2018; Van Gils and Zwart, 2009). It is suggested that learning between a small firm and its large partner involves each other's resources integrated into a collaborative interaction process (McEvily and Marcus, 2005; Woldesenbet, Ram and Jones, 2011; Hashai, 2018). When facing collaboration challenges, small firms identify problems and develop solutions with their large partners (Perrons, 2009; Skarp and Gadde, 2008). For example, Dutta and Hora (2017) suggest that small firms rely on their large partners to commercialize their technologies. Martin-Rios and Erhardt (2016) indicate that small firms collaborate with their large partners to overcome technological challenges. This joint problem-solving process can be crucial for the small firms to achieve the improvements necessary to remain competitive (Ragatz, Handfield, and Scannell, 1997). While these studies anchor their focus on the operational aspect of joint actions, other scholars indicate that alliance firms should also devote their attention to the cognitive aspect of joint actions, i.e., joint sensemaking. Revilla and Villena (2012), for example, argue that joint sensemaking helps 'develop mental models and frameworks that play key roles in integrating and reconciling their individual understandings' (p. 856). Such reconciled understandings ensure that a small firm obtains knowledge about the strategic issues of the relationship and thus motivate it to conduct learning within its organisational boundary (e.g., Hult et al., 2004). For instance, Van Gils and Zwart's (2009) study of alliance formation motives indicates how small firms and their partners make sense of their collaboration. In this regard, joint sensemaking captures joint actions that are more critical and of greater strategic importance to the relationship than joint problem-solving, which only involves operational issues. Since these two types of joint actions refer either to the operational (i.e., problem-solving) or the cognitive (i.e., sensemaking) aspect of partner involvement, we are able to compare across multiple actions when discussing their effects on small-firm knowledge exploration and exploitation. 
On the other hand, asymmetric alliances differ from reciprocal, mutually dependent relationships that have been referred to in most alliance studies (e.g., Li, Eden, Hitt, and Ireland, 2008; Wassmer and Dussauge, 2011) in that they highlight small firm's capability disadvantages when collaborating with large partners (Ireland and Webb, 2007). While a small firm may have an advantage in a segment technology domain over its large partner, it is normally associated with weaker capabilities in integrating multiple technologies into a product system and competing in the market. Small firms are thus largely dependent on their large partners to pursue market value (e.g., Stuart, Hoang, and Hybels, 1999). Due to dependence asymmetry, it has been suggested that the value created by a small firm-large firm alliance is appropriated by the large firm (Rothaermel, 2001), which results in a less successful alliance relationship (Lerner, Shane, Tsai, 2003). In view of this, Katila et al. (2008) posited that small firms will conduct learning and innovation only when they have effective defence mechanisms. Similarly, Yang et al. (2014) argued that small firms allying with large firms benefit more from knowledge exploitation than from exploration, and will only increase the value of such exploration if they can manage the alliances with proper alliance governance.

Combining these two streams of literature (i.e., joint actions and alliance governance), a small firm allying with a large firm encounters a collaborative tension: on the one hand, the small firm needs to be deeply involved in joint activities to conduct learning; on the other hand, excessive joint actions increase the likelihood of knowledge misappropriation by the large firm. While it is acknowledged that a small firm relies on large partners to learn and grow (Stuart et al., 1999; Perrons, 2009), the consideration of this tension leads us to ask how joint actions with large firms affect small-firm learning. In this study, we study small firm's joint sensemaking and joint problem-solving actions with large partners, introducing relational identification as a motivational force behind small-firm knowledge exploration and exploitation.

\section{Relational identification between alliance firms}

Social identification demonstrates 'the perception of oneness with or belongingness to some human aggregate' (Ashforth and Mael, 1989: 21). At the organisational level, individuals identify with referents such as coworkers, leaders, or subordinates within their organisational lives. Such an 
identification process highlights a role-related relationship that an individual embeds in (Slush and Ashforth, 2007). This relates to what Brewer and Gardner (1996) referred to as the 'relational self', that is, the understanding of self has to be reached with reference to a specific relationship. Following this notion, Slush and Ashforth (2007: 11) conceptualized relational identification as 'the extent to which one defines oneself in terms of a given role-relationship'. At the core of the concept, relational identification rests in the relationship itself rather than in an individual that one identifies with (Slush and Ashforth, 2008).

Derived from social identification at the organisational level, scholars have referred to relational identification between organisations (Ellis and Ybema, 2010; Ireland and Webb, 2007). According to Corsten et al. (2011), identification at the interfirm level demonstrates the perceived oneness of an alliance firm with its partner. When an alliance firm perceives an overlap between its own identity and the alliance partner's identity, it identifies with this partnership. The focus of identification here is the relationship that informs the roles and identities of partner firms. This departs from what Mitchell, Agle, and Wood (1997) termed as stakeholder identification as they emphasized the identification with an entity instead of with a relationship. Specifically, relational identification in alliances entails a process of partnership-based identification and results in the clarification of a firm's distinctive and unique functions in the collaborative relationship (Hogg, van Knippenberg, and Rast, 2012), thereby determining a firm's perception of itself in terms of a given alliance relationship (Bhattacharya and Sen, 2003). It is suggested that relational identification includes at least two aspects: emotional aspect and perceptual aspect (e.g., Van der Vegt and Bunderson, 2005), both of which reflect the extent to which one defines its identity based on an ongoing partnership. The emotional aspect of relational identification reflects 'the self defined in terms of the relationship [between one's own firm and a partner firm]' (Hogg et al., 2012: 239). It highlights the emotional significance of attaching to a partnership (Bishop and Scott, 2000), thereby demonstrating the self-definition of its identity in terms of this partnership. In contrast, the perceptual aspect of relational identification concerns how an alliance firm perceives the value, meaning, or strategic importance of the partnership (e.g., Parent and Deephouse, 2007). Brickson (2007), for example, argued that 'the relational statements [of identity] portray an emphasis on the well-being of particular outsiders and insiders with whom their members 
perceive organisations as having meaningful relationships' (p.2006). When an alliance firm perceives a high value of a partnership, it is likely that this firm defines its identity by attaching itself to this partnership.

Relational identification provides a small firm with a lens for interpreting its partnership with large firms (e.g., Peteraf and Shanley, 1997). It explains what the alliance relationship means to the small firm (Ireland and Webb, 2007) and has motivational and behavioral consequences (Ahearne, Bhattacharya, and Gruen, 2005). The process of identifying with a relationship entails the possibility that the small firm 'aligns its values and beliefs in relation to the characteristics and actions of the relationship' (Sammarra and Biggiero, 2001: 68). A small firm identifying with its alliance partnership can be motivated to share explicit information and tacit knowledge (Dyer and Nobeoka, 2000; Martin-Rios and Erhardt, 2016), strengthen its partnership (Ireland and Webb, 2007; Shaw et al., 2017), and jointly improve productivity and relationship performance (Dyer and Hatch, 2004; Hashai, 2018). Because a small firm is normally highly dependent on its large partner in an asymmetric alliance (Wassmer and Dussauge, 2011), relational identification can be crucial in driving its risk-taking activities.

\section{Joint actions and small-firm relational identification}

Joint sensemaking is a fundamental social process: organisations jointly interpret and comprehend the collaboration challenges that are associated with the environment, and construct strategies to act collectively (Maitlis, 2005). To conduct joint sensemaking is to develop a shared understanding of strategic issues for the relationship, such that both partner firms sense the meaning of collaboration (Seidl and Werle, 2018). This requires each of the partner firms to explore relationship-specific knowledge and to reconcile their recognition of how strategically the relationship should be managed (Fugate et al., 2009). Consequently, the partner firms can integrate each other's understanding of the relationship and develop collective strategies (Hult et al., 2004). Research on the social processes of organisational sensemaking has tended to focus on how certain groups influence other's understanding of issues (Smircich and Stubbart, 1985). For a small firm that has lower bargaining power than its large partner, joint sensemaking activities can be crucial to shaping aspiration and 
affirmation (e.g., Frazier and Rody, 1991). The large partner can thus exert extensive influence on the small firm in shaping a shared understanding of the vision and strategies of the collaborations (Gawer and Phillips, 2013). While the dominance the large partner holds over the small firm may lead to disagreements (Gaski, 1984), joint sensemaking activities are able to resolve such disagreements via shared understandings of strategic issues in the partnership. When the strategic views of both parties converge, the small firm is likely to accept the large partner's dominance and acknowledge its leading status (Perrons, 2009). Also, joint sensemaking activities with a large partner, such as scanning and interpretation of the market they face, significantly influence a small firm's understanding of the collaboration, thereby strengthening collective action (Weick, 1993). According to Dyer and Nobeoka (1994), this will increase the strength of the small firm's relational identification because it perceives an overlap between its own attributes and the large partner's.

Moreover, the involvement in joint sensemaking activities comprises highly animated interaction processes in order to achieve reciprocal outcomes, which strengthen a small firm's identification with the alliance relationship (e.g., Scott and Lane, 2000). Joint sensemaking requires both parties to be active 'sense-givers' who construct and promote understanding and explanations of events and collaboration challenges. Based on the principal of fair exchange (Lane and Beamish, 1990), a sustainable relationship can be maintained when a small firm believes it receives benefits from the relationship that equal its contributions. This will help to diffuse and institutionalize norms and expectations (Oliver, 1991), which in turn leads to a situation in which the small firm identifies with the relationship (Rowley, 1997). Revilla and Villena (2012) suggest that when partner firms interact, they develop mental models and frameworks that help with close collaboration. This interaction increases the mutual awareness of distinctive and unique functions in the collaborative relationship, and strengthens the shared attributes within the alliance and, thus, leads the small firm to form relational identification.

Hypothesis 1a: The more joint sensemaking activities there are with a large partner, the more likely a small firm is to strengthen its relational identification with the partnership.

Similarly, we posit that joint problem-solving activities exhibit a positive association with the 
potential for the small firm to strengthen relational identification. McEvily and Marcus (2005) suggest that joint problem-solving between alliance partners begins with problem identification. Through exchanging perceived problem content and the negotiation of the mutual adaptations required, alliance partners jointly resolve their difficulties. Kale, Singh, and Perlmutter (2000) demonstrate that engagement in joint problem-solving fosters close collaboration between the alliance partners and creates a more conducive environment for future cooperation. Small firms engaging in joint problem-solving activities with large partners can facilitate information sharing and effective communication, encouraging both parties to use and apply their expertise and resources in alliance activities to meet the obligations of, and make the promised contributions to, the alliance (McEvily and Marcus, 2005; Thorgren, Wincent, and Örtqvist, 2012). Through recursive engagements, small firms obtain help from large partners and thus, shape the perception of collaboration value and the identification with the relationships (Miller, 2002). In the case that a large partner's dominance in the collaboration process causes disagreements, such engagements can help the large partner convey the signal that it is striving to contribute to the relationship rather than appropriating the small firm's interests (e.g., Dyer and Nobeoka, 2000). This can be helpful in easing the small firm's concerns of knowledge misappropriation, which predicts stable exchange relationships (Van de Ven and Walker, 1984). Given the substantial capability advantages large partners hold over small firms, those conducting joint problem-solving activities could easily obtain legitimacy and affirmation (e.g., Gawer and Phillips, 2013), thereby increasing the likelihood that the small firm identifies with the relationship (Ireland and Webb, 2007).

Rather than holding back information or taking unfair advantage of each other, joint problem-solving emphasizes the progress that can be made if both parties work through the difficulty and produce all the mutual benefits possible from the cooperation (McEvily and Marcus, 2005). Such a process can help generate a mutually satisfactory solution for every contingency and contribute to a stronger relationship between partners (Claro, Hagelaar, and Omta, 2003). Strong norms of reciprocity would then be developed in the relationship where there is a sense of give-and-take between the large partner and small firm based on their respective contributions. As a result, this kind of interactive relationship strengthens the small firm's commitment to the relationship, which provides a backdrop 
for relational identification (Scott and Lane, 2000).

Hypothesis 1b: The more joint problem-solving activities there are with a large partner, the more likely a small firm is to strengthen relational identification with the partnership.

\section{Small-firm relational identification and knowledge exploration and exploitation}

Social identification theorists (e.g., Turner, 1975) have attributed the determinants of learning to the development of self-conceptions that affiliate or connect with other social groups. The core argument is that the "extent to which people identify with a particular social group determines their inclination to behave in terms of their group membership' (Ellemers, Kortekaas, and Ouwerkerk, 1999, p. 372). According to Ahearne et al., (2005), relational identification between organisations has motivational consequences. The increased strength of relational identification motivates a small firm to-in conjunction with its large partner-create new, innovative ways of combining existing knowledge-related capabilities and resources in order to explore uncertain knowledge domains (Cullen, Johnson, and Sakano, 2000) or to exploit existing technologies (Stettner and Lavie, 2014). The greater the possibility of forming relational identification, the stronger the commitment will be. The small firm then has a stronger motivation to explore unknown technological areas so that it can increase its contributions to the partnership. It will also increase the small firm's motivation to exploit and refine existing technologies so as to create additional value for the relationship (e.g., Kiss, Fernhaber, and McDougall-Covin, 2018; Wang, Luo, Maksimov, Sun, and Celly, 2019). Because relational identification leads to a close relationship (Ireland and Webb, 2007), it can help ease a small firm's concerns of the risk of knowledge appropriation by its large partner (Katila et al., 2008). The small firm can then focus on knowledge exploration and exploitation activities to increase the shared outputs (e.g., Zeng and Chen, 2003). In general, a small firm allies with a large partner to pursue specific alliance objectives. While these are normally associated with responsibilities and burdens, relational identification with a large partner encourages the small firm to deploy relation-specific investments and to undertake such responsibilities (Corsten et al., 2011). This may further motivate the small firm to take the risks of knowledge exploration and exploitation so that the alliance objectives can be achieved. Also, the pursuit of alliance objectives may relate to rewards that the 
small firm can receive from its large partner. When the small firm identifies with its large partner, it will have a strong motivation to win such rewards so that the partnership can be extended (Dyer and Nobeoka, 2000), which further encourages it to explore unknown technological areas or exploit existing knowledge domains.

Hypothesis 2a: The more likely a small firm is to strengthen relational identification with its partnership, the more frequently it will engage in knowledge exploration.

Hypothesis 2b: The more likely a small firm is to strengthen relational identification with its partnership, the more frequently it will engage in knowledge exploitation.

\section{The mediation effects of relational identification on joint actions and small-firm exploration}

We argue that joint sensemaking spurs knowledge exploration when it favors the strengthening of a small firm's relational identification; that is, relational identification mediates the relationship between joint sensemaking and exploration. Specifically, joint sensemaking ensures effective communication as a means to stimulate small-firm exploration, while whether the small firm conducts exploratory activities is affected by its potential to identify with the collaborative relationship. According to situated learning theory (Lave and Wenger, 1991), 'knowledge is not primarily abstract and symbolic, but is provisional, mediated, and socially constructed' (Handley, Sturdy, Fincham, and Clark, 2006: 642). As a social good, novel knowledge can be created through strengthening a creator's identification with its social group (Dyer, 1997). When joint sensemaking helps foster small firms' relational identification, the concern of knowledge misappropriation may be mitigated, which will have a positive impact on their exploration behaviors (Katila et al., 2008). Further, a small firm identifying with a collaborative relationship will have a strong motivation to conduct knowledge exchange with its large partner (Füller, Matzler, and Hoppe, 2008). By obtaining knowledge that departs from its own knowledge stock, the small firm is able to conduct exploration in uncertain technological areas (Choi and Mcnamara, 2018; Hashai, 2018). When joint sensemaking activities increase, the likelihood that the small firm identifies with the collaborative relationship increases, thereby promoting the small firm to pursue exploration. In this sense, joint sensemaking activities in an asymmetric alliance will first stimulate the small firm's identification with the relationship, which 
then leads the small firm to invest in and absorb highly tacit and diverse knowledge for exploratory learning.

In a similar vein, we argue that a small firm's relational identification mediates the relationship between joint problem-solving with its large partner and the small firm's exploration. Joint problem-solving has been considered an effective mechanism through which a focal firm develops innovation (Perrons, 2009). However, exploratory learning is a risk-taking process (McGrath, 2001). Without commitment to a relationship, the small firm may not attempt it. Relational identification promotes relation-specific investments that act as a means of enhancing commitment (Corsten et al., 2011), thereby motivating the small firm to pursue exploration through joint problem-solving. Moreover, joint problem-solving involves knowledge-related activities. Given that the small firm identifies with the collaborative relationship in the process of joint problem-solving, its attitude towards knowledge searching and learning in the relationship will be boosted, which is beneficial to exploration (Füller et al., 2008). The more frequently the large partner is involved in joint problem-solving activities, the higher the potential for the small firm to strengthen relational identification and thus the more likely it is to conduct knowledge exploration.

Hypothesis 3a: A small firm's relational identification mediates the relationship between its joint sensemaking with its large partner and the small firm's exploration.

Hypothesis 3b: A small firm's relational identification mediates the relationship between its joint problem-solving with its large partner and the small firm's exploration.

\section{The mediation effects of relational identification on joint actions and small-firm exploitation}

From the knowledge-based perspective, joint sensemaking with large partners may influence small-firm knowledge exploitation as they provide access to complementary knowledge (Yang et al., 2014). Yet a small firm might not be motivated to conduct knowledge exploitation due to concerns of possibly damaging misappropriation of its knowledge and resources by the large partner (Katila et al., 2008). This points to the small firm's perception and identification of the relationships with the large partner in terms of meaning and value (Parent and Deephouse, 2007). Joint sensemaking promotes a small firm's understanding of a relationship and then strengthens its identification with that 
relationship (Weick, 1993), which subsequently revises the small firm's motivation to conduct exploitative learning. When a small firm identifies with the relationship with its large partner, it will hold intensive interactions with this partner. Such a process repeatedly exposes the small firm to the discussion of problems and possible solutions, which facilitates knowledge flow between the two partners (McEvily and Marcus, 2005). The small firm will then be able to maintain productivity and achieve organisational renewal (Benner and Tushman, 2003; Stettner and Lavie, 2014). We thus argue that joint sensemaking affects small-firm knowledge exploitation via strengthening relational identification, that is, relational identification mediates the relationship between joint sensemaking and small-firm knowledge exploitation.

Similarly, we posit that relational identification mediates the relationship between joint problem-solving and small-firm knowledge exploitation. While exploitative learning entails lower risks than exploration (Rothaermel and Deeds, 2004), it still requires a small firm to invest plenty of resources. The lack of identification with the partnership may hinder the small firm from making such an effort. Joint problem-solving promotes interfirm communication and information sharing (McEvily and Marcus, 2005), which help shape a small firm's perception of worth and consequently strengthen its identification with the partnership. The small firm could then have an increased motivation to contribute to the partnership by exploiting and improving the existing technologies (Stettner and Lavie, 2014). In addition, the increased likelihood of shaping relational identification may lead to increased mutual understanding, which creates a basis for future integration of knowledge (Auh, Bell, McLeod, and Shih, 2007). It may also foster openness and reciprocity in the process of interfirm coordination (Muthusamy and White, 2005). When the small firm conducts joint problem-solving with its large partner, the shaped relational identification may facilitate knowledge transfer between the partner firms (Füller et al., 2008). By applying acquired knowledge to the development of the existing technologies, the small firm is able to make major improvement to their products.

Hypothesis 4a: A small firm's relational identification mediates the relationship between joint sensemaking with its large partner and the small firm's knowledge exploitation.

Hypothesis 4b: A small firm's relational identification mediates the relationship between joint problem-solving with its large partner and the small firm's knowledge exploitation. 


\section{METHODOLOGY}

\section{Sample and data collection}

Our empirical setting is China's high-tech industries, which have been deemed of strategic importance by the central government because of their role in boosting economic growth and promoting technological innovation. Firms in these industries are all knowledge-intensive, with a large number of them developing cutting-edge technologies, making them a fertile setting for scrutinizing the phenomenon of knowledge exploration and exploitation. We first contacted the regional Science and Technology Departments in the Pearl River Delta, Yangtze River Delta, and Beijing district- the three most developed areas in China, and obtained a list of 6,712 high-tech firms. We then excluded 2,337 firms with revenue of more than $\$ 100$ million to ensure that our sample did not include large firms (Yang et al., 2014). We also excluded 459 firms that had no contact information. Lastly, we randomly selected 500 small and medium-sized firms from the remaining list. We designed our questionnaire in English and translated it into Chinese, with a back-translation process. To ensure face and content validity, we interviewed 21 managers and scholars, and refined the scale items based on their suggestions. A pretest was conducted before finalizing our questionnaire.

Since the choice of single informant has been widely used in survey studies (e.g., Carlson and Kacmar, 2000; Li and Zhang, 2007), we selected one informant (top manager or senior manager from marketing/R\&D department) from each firm (Li, Poppo, and Zhou, 2010). We conducted the survey between May and October 2014 using a computer-based approach (Rodan and Galunic, 2004). We invited local government departments such as Department of Science and Technology to be involved in the survey coordination to ensure a high response rate (cf. Zhao and Chadwick, 2014). Because our focus was on asymmetric alliance, we asked the informants whether their firms had been or were currently involved in relationships with partners significantly more advantageous than themselves regarding revenue, technological capability, reputation, or position in the value chain. The informants' subjective judgments helped exclude 38 firms. We then followed Yang et al. (2014) who defined small firms as those with revenue of less than $\$ 100$ million and large firms as those with revenue of 
more than $\$ 1$ billion to examine whether the sample firms had large partners with annual revenue of more than 10 times of theirs. All the remaining sample firms met the criterion. We phoned the informants and sent them the computer-based questionnaire and our contact information by email. The informants were ensured that their responses were anonymous and confidential (Podsakoff, MacKenzie, Lee, and Podsakoff, 2003). A follow-up email was sent if the questionnaire had not been returned three days thereafter.

Overall, we received valid and completed questionnaires from 205 firms. Of the responding firms, $41.5 \%$ were in the electronic and information technology industry, $16.1 \%$ were in the new energy and new material industries, $19.5 \%$ were in the mechanical and electronic equipment industries, $10.2 \%$ were in the new pharmaceuticals and bioengineering industries, and $12.7 \%$ were in other industries such as aerospace and semiconductors. We checked the non-response bias by comparing earlier responders with later responders, and by comparing responding firms and non-responding firms in terms of firm age and size; neither suggested a significant difference.

\section{Measurements}

Our measurements of dependent and explanatory variables were all multi-item and were assessed using 7-point Likert scales (1=strongly disagree, $7=$ strongly agree). We averaged the items to create the scores for the constructs.

Dependent variable. We measured exploration and exploitation using items adapted from $\mathrm{He}$ and Wong (2004). Exploration was measured by indicating the extent to which a firm's innovation: (1) introduces a new generation of products; (2) extends a product range; (3) opens up new markets; (4) enables it to enter new technology fields. Exploitation was measured by indicating the extent to which a firm's innovation: (1) improves existing product quality, (2) improves production flexibility, (3) reduces production costs, and (4) improves yields or reduces material consumption.

Explanatory variables. Following Revilla and Villena (2012), we measured joint sensemaking by assessing the extent to which the sample firms and their large partners shared a sound understanding of the (1) changes in customer needs and preferences; (2) experiences of success and failure in similar relationships; and (3) changes in technology. Joint problem-solving was measured using three items 
adapted from McEvily and Marcus (2005). The respondents were asked to rate the extent to which they agreed with the following statements: (1) 'Our main partner works with us to overcome difficulties'; (2) 'We are jointly responsible with our main partner for getting things done'; and (3) 'We work with our main partner to help solve each other's problems'. To measure relational identification, we reviewed the literature and developed the items based on existing studies. Our review of the literature suggested that relational identification includes at least two aspects: an emotional aspect and a perceptional aspect. We followed Van der Vert and Bunderson (2005) and adopted two items (see the following first two of the three items) to capture the emotional aspect of relational identification. We then followed Brickson (2007) and included one additional item investigating the informant's perception and evaluation of the relationships with their partners. Specifically, we asked informants to rate the extent to which their organisational members, 'feel emotionally attached to the collaborative relationship', 'feel as if any problems concerning the relationship are their own', and 'feel that the relationship with the main partner is meaningful'.

Control variables. To rule out alternative explanations, we controlled for a number of factors. At the firm level, we controlled for firm age (the number of years since founding), firm size (the natural $\log$ of the number of employees), type of industry $(0=$ electronic and information technology, 1=otherwise), and R\&D competence. Firm age, firm size, and type of industry are associated with the amount of risk during the exploration process (Stuart et al., 1999). R\&D competence, which is defined as the ability to develop new technological expertise (Danneels, 2002), may also affect a firm's decisions on knowledge exploration (Ofek and Sarvary, 2003). We measured R\&D competence using a three-item scale adapted from Yam, Lo, Tang, and Lau (2011). The respondents were asked to evaluate the following statements regarding their competence: (1) high quality and quick feedback from manufacturing to design and $\mathrm{R} \& \mathrm{D},(2)$ the great extent of market and customer feedback into the technological innovation process, (3) the sound mechanisms for transferring technology from research to product development. At the relationship level, we controlled for the duration (the number of years of collaboration), the existence of equity crossholding ( $1=$ yes, $0=$ no), and relationship substitutability, which indicated the possibility of finding a new relationship to replace the original one. These relationship elements may relate to the extent to which a firm makes a commitment to its partner and, 
thus, its willingness to conduct exploration (Rothaermel and Deeds, 2004). Because environmental factors may be related to a firm's knowledge activities, we also controlled for competition intensity as an environmental variable, with three items adapted from Zhou and Li (2012) reflecting the situations of promotion wars, competitive responses, and the extent of intensity.

\section{Construct validity}

We used confirmatory factor analysis to assess the psychometric properties of the multi-item scales used to measure the constructs (see the Appendix). The measurement model fit well with the data (CMIN/DF $=2.132, p=0.000$, goodness-of-fit index $[\mathrm{GFI}]=0.901$, comparative fit index $[\mathrm{CFI}]=0.935$, incremental fit index $[\mathrm{IFI}]=0.937$, root mean square error of approximation $[\mathrm{RMSEA}]=0.061$ ). All items significantly loaded on the corresponding latent constructs $(\mathrm{p}=0.000)$, with standardized factor loadings all above the recommended 0.4 benchmark for the social sciences (Ford, McCallum, and Tait, 1986), thus showing the unidimensionality and convergent validity (Anderson and Gerbing, 1988). We assessed the reliability of the constructs with Cronbach's alpha, and all constructs except relational identification had reliabilities higher than the threshold of 0.7. The Cronbach's alpha for relational identification was 0.62 , which is acceptable for questionnaire measures (Zhao and Chadwick, 2014). We thus concluded that our measure of relational identification demonstrated adequate reliability. To assess discriminate validity, we ran a series of chi-square difference tests to compare the constrained model with an unconstrained model. In every case, the chi-square differences were significant, in support of discriminant validity. For example, the chi-square difference test for joint problem-solving and joint sensemaking yields $21.4(\mathrm{p}=0.000)$. We also checked if the 95 percent confidence interval around the correlation estimates between each pair of constructs included a value of one; the results suggested that no value of one existed, again showing discriminant validity (Anderson and Gerbing, 1988). The means, standard deviations and intercorrelations for the variables of interest are summarized in Table 1. 


\section{Common method biases tests}

We used Harman's one-factor test to check for the potential of common method bias (Podsakoff and Organ, 1986). We subjected all measure items of the multi-item variables to a factor analysis. The solution accounted for 66.13 percent of the total variance, and the first factor represented only 15.92 percent. In addition, because common method bias indicates that respondents might answer socially sensitive or potentially primed questions in a particular way (Podsakoff et al., 2003), the answers to those questions should vary less than others (Ozer and Zhang, 2015). We thus checked the variances of the explanatory and dependent variables and found no significant differences (ranging from 0.755 to 1.077). Lastly, following Podsakoff et al.'s (2003) recommendation, we added an artificial common method variable into our measurement model, with all items loaded on this variable and on the seven multi-item variables simultaneously. The fit indices were slightly better than that of our seven-factor model $(\mathrm{CMIN} / \mathrm{DF}=1.637 ; \mathrm{GFI}=0.909, \mathrm{CFI}=0.947, \mathrm{IFI}=0.948, \mathrm{RMSEA}=0.056)$. While the chi-square significantly decreased $\left(\Delta \mathrm{X}^{2}=15.549, \Delta \mathrm{df}=1, \mathrm{p}=0.000\right)$, the variance extracted by the common method factor was 0.285 , well below the threshold of 0.5 , again ruling out the presence of common method biases.

\section{ANALYSIS AND RESULTS}

We chose both a causal step method and bootstrapping approach to test the mediating effect of relational identification on the relationship between joint actions with large partners and small-firm exploration. The causal step method was used to estimate the parameters of our model by conducting hierarchical regression with robust standard errors (Baron and Kenny, 1986). To further confirm the results of the causal step analysis, we introduced the bootstrapping approach (Shrout and Bolger, 2002; Preacher and Hayes, 2008). Since the bootstrapping approach is a nonparametric test, it is recommended for small sample sizes; our use of this approach may thus have improved the robustness of the results (Preacher and Hayes, 2008).

\section{Causal step method}


Table 2 shows the regression results considering relational identification as the dependent variable. Model 1 only introduced control variables, Model 2 added the main effect of joint sensemaking, and Model 3 added the main effect of joint problem-solving. The results indicate that both joint sensemaking and joint problem-solving are positively associated with a small firm's relational identification (Model 2: $\mathrm{b}=0.301, \mathrm{p}<0.01$; Model 3: $\mathrm{b}=0.379, \mathrm{p}<0.01$ ), thus supporting hypothesis $1 \mathrm{a}$ and $1 \mathrm{~b}$.

\section{-------Insert Table 2 about here-------}

Table 3 presents the regression results for knowledge exploration and exploitation. Models 4 and 10 only introduced control variables. Models 5 and 11 added the effect of joint sensemaking. Models 6 and 12 added the effect of joint problem-solving. Models 7 and 13 added the effect of relational identification. Models 8 and 14 included controls and joint sensemaking and relational identification. Models 9 and 15 included controls and joint problem-solving and relational identification. As shown in Model 7, the relationship between relational identification and knowledge exploration is significant and positive $(\mathrm{b}=0.166, \mathrm{p}<0.01)$, in support of hypothesis $2 \mathrm{a}$. As shown in Model 13, the relationship between relational identification and knowledge exploitation is significant and positive $(b=0.130, p<$ $0.05)$, in support of hypothesis $2 \mathrm{~b}$.

\section{-------Insert Table 3 about here-------}

In hypothesis 3a, we proposed that a small firm's relational identification mediates the relationship between joint sensemaking with its large partner and the small firm's exploration. The correlations between joint sensemaking and relational identification, and between relational identification and knowledge exploration are both significant; As shown in Model 8, the correlations between joint sensemaking and knowledge exploration are significant $(b=0.112, \mathrm{p}<0.1)$, and are subject to a slight decrease after adding relational identification $(b=0.137, p<0.05)$. While these results suggest partial 
mediation, we further conducted a Sobel test (Sobel, 1982) to recheck the mediating effect. The result indicates that the null hypothesis $\mathrm{a} \times \mathrm{b}=0$ is rejected $(\mathrm{t}=1.831, \mathrm{p}<0.1)$, thereby providing support for hypothesis $3 \mathrm{a}$.

In hypothesis $3 b$, we proposed that a small firm's relational identification mediates the relationship between joint problem-solving with its large partner and the small firm's exploration. While the correlations between joint problem-solving and relational identification, and between relational identification and knowledge exploration were both significant, the correlation between joint problem-solving and knowledge exploration in Model 6 were insignificant $(b=0.073, p>0.1)$. These results could not support or reject hypothesis $3 \mathrm{~b}$. We thus rechecked the mediating effect using the Sobel test. The result shows that the null hypothesis $\mathrm{a} \times \mathrm{b}=0$ is rejected $(\mathrm{t}=2.130, \mathrm{p}<0.05)$. Hypothesis $3 \mathrm{~b}$ is thus supported.

In hypothesis $4 \mathrm{a}$, we posited that a small firm's relational identification mediates the relationship between joint sensemaking and small-firm knowledge exploitation. Model 14 suggests that when entering both joint sensemaking and relational identification, the effect of joint sensemaking on exploitation is still significant and positive $(b=0.137, p<0.05)$, while the effect of relational identification on exploitation is not significant $(b=0.094, p>0.1)$. Combining the results of hypotheses 1a and 2b, we could not accept or reject hypothesis $4 \mathrm{a}$. The result of the Sobel test provides preliminary support for hypothesis $4 \mathrm{a}(\mathrm{t}=1.784, \mathrm{p}<0.1)$.

In hypothesis $4 b$, we posited that a small firm's relational identification mediates the relationship between joint problem-solving and small-firm knowledge exploitation. The results of Model 15 suggest that the simultaneous inclusion of relational identification and joint problem-solving leads to a significant effect of the former $(b=0.113, p<0.05)$ and an insignificant effect of the latter $(b=0.046, p$ $>0.1$ ). Combining the results of hypotheses $1 \mathrm{~b}$ and $2 \mathrm{~b}$, we can reach the conclusion of a significant mediation effect, which was again supported by the result of the Sobel test $(\mathrm{t}=1.909, \mathrm{p}<0.1)$. Therefore, hypothesis $4 \mathrm{~b}$ is supported. 


\section{Bootstrapping approach}

To further examine the mediating role of relational identification in the relation between joint actions and small-firm ambidexterity, we adopted the bootstrapping approach to estimate this indirect effect (Preacher and Hayes, 2008; MacKinnon, Lockwood, and Williams, 2004). In this study, a 95\% confidence interval of the indirect effects was obtained with 5,000 bootstrap resamples (Preacher and Hayes, 2008). We first introduced joint sensemaking as the independent variable. As shown in Figure 1a, joint sensemaking was positively associated with relational identification $(b=0.29, p<0.01)$, and with knowledge exploration $(\mathrm{b}=0.24, \mathrm{p}<0.01)$. It was also found that relational identification was positively related to knowledge exploration $(\mathrm{b}=0.12, \mathrm{p}<0.05)$. When controlling for relational identification, the relationship between joint sensemaking and knowledge exploration was still significant $(b=0.21, p<0.01)$. We then checked the indicators of the bootstrapping analyses. It was found that the confidence interval did not include zero (lower limit $=0.0015$, upper limit $=0.0768$ ), again in support of hypothesis $3 \mathrm{a}$.

Insert Figure 1 about here-------

-------Insert Table 4 about here-------

Using a similar approach, we re-examined the results of H3b (Figure 1b). First, our results showed that joint problem-solving was positively associated with knowledge exploration $(b=0.14, p<0.05)$. It was also found that joint problem-solving was positively related to relational identification $(b=0.39, p$ $<0.01)$. Lastly, the results indicated that the mediator, relational identification, was positively associated with knowledge exploration $(b=0.14, p<0.05)$. The results of the bootstrapping analyses confirmed that relational identification mediates the relationship between joint problem-solving and knowledge exploration $(b=0.05$, confidence interval $=0.0079$ to 0.1096$)$ (Table 4). Moreover, when controlling for relational identification, the direct effect of joint problem-solving on knowledge exploration became insignificant $(b=0.08, p>0.1$ ), in support of full mediation (hypothesis $3 b$ ).

As shown in Figure 1c, joint sensemaking was positively associated with relational identification 
$(b=0.29, p<0.01)$, and with knowledge exploitation $(b=0.27, p<0.01)$. It was also found that relational identification was positively related to knowledge exploitation $(b=0.12, p<0.05)$. When controlling for relational identification, the relationship between joint sensemaking and knowledge exploitation was still significant $(b=0.24, \mathrm{p}<0.01)$. Nevertheless, the results of the bootstrapping analyses suggested that the confidence interval included zero (lower limit $=-0.0001$, upper limit $=0.0825)$, thus not supporting hypothesis $4 \mathrm{a}$. Given that the bootstrapping approach is considered to be more robust than the causal step method (Preacher and Hayes, 2008), we concluded that hypothesis $4 \mathrm{a}$ was not supported.

As shown in Figure 1d, joint problem-solving was positively associated with knowledge exploitation $(b=0.19, p<0.01)$, and with relational identification $(b=0.40, p<0.01)$. The results also suggest that relational identification positively relates to exploitation $(b=0.13, p<0.05)$. When controlling for relational identification, the relationship between joint problem-solving and knowledge exploitation was still significant $(b=0.14, p<0.05)$. We then checked the indicators of the bootstrapping analyses. It was found that the confidence interval did not include zero (lower limit $=0.0019$, upper limit $=0.1173$ ), thus supporting hypothesis $4 \mathrm{~b}$.

\section{DISCUSSION AND CONCLUSION}

This study investigates how relational identification affects the relationship between joint actions and a small firm's knowledge exploration and exploitation in an asymmetric alliance. Using survey data on 205 high-technology firms in China, the results suggest that joint problem-solving and joint sensemaking with a large partner both strengthen a small firm's relational identification, and that relational identification promotes small-firm ambidexterity. More importantly, we find that relational identification mediates the relationship between joint sensemaking and exploration, as well as the relationship between joint problem-solving and exploration. Our analysis also supports the mediating effect of relational identification in the relation between joint problem-solving and exploitation. However, we fail to find support for the mediating role of relational identification in the relation between joint sensemaking and knowledge exploitation. One possible interpretation is that joint 
sensemaking represents interaction at the strategic level and has motivational consequences (e.g., Brunner-Sperdin, Scholl-Grissemann, and Stokburger-Sauer, 2014), which is similar to the effect of relational identification in our study. When a small firm conducts joint sensemaking activities with its large partner, it will be motivated to bear the burden of conducting exploitative activities (Revilla and Villena, 2012), even in the absence of relational identification. This differs from the situation of exploration as it relates to higher risks than exploitation (Yang et al., 2014). In other words, joint sensemaking affects small firm's knowledge exploitation in a direct (as shown in Model 11 of Table 3) rather than an indirect way.

\section{Contributions}

Our study contributes to asymmetric alliance literature (e.g., Kalaignanam et al., 2007) by revealing whether different types of joint actions with large partners might affect small-firm ambidexterity in different ways. Prior literature has investigated the relationship between joint actions with large partners and small firms' learning (e.g., Dyer and Nobeoka, 2000; Gawer and Phillips, 2013). Yet these studies failed to examine how such a relationship works and whether it is the same for exploitative and exploratory learning. By introducing the mediating role of relational identification, our study contributes to this line of inquiry and finds out that the impacts of joint actions on small-firm ambidexterity can be either indirect or direct. Specifically, focusing on two different types of joint actions a small firm may engage in, in pursuit of knowledge exploration and exploitation: joint sensemaking and joint problem-solving, our analysis demonstrates the indirect effects of joint problem-solving on small-firm exploration and exploitation, as well as of joint sensemaking on small-firm exploration. Such indirect effects contrast with a direct impact of joint sensemaking on knowledge exploitation as shown in our analysis. Hence, our study provides a more nuanced view of how joint actions might exert diverse impacts on exploration versus exploitation.

By incorporating relational identification into our investigation of the relationship between joint actions and ambidexterity, our study also helps provide an alternative explanation of how collaboration between small and large firms promotes the small firm's learning. Prior literature examining asymmetric relationships and ambidexterity focuses predominantly on knowledge access 
and integration (e.g., Gawer and Cusumano, 2002; Perrons, 2009). We contribute to this stream of work by arguing that the mechanism through which joint actions affect small firm's knowledge exploration and exploitation refers to the strength of relational identification. Our findings provide evidence that the benefits joint actions have on exploration and exploitation may not be fully realized unless the small firm identifies with the relationship with its large partner. Given that learning between small and large firms often refers to the risk of knowledge misappropriation (Katila et al., 2008; Knoben and Bakker, 2019), our conceptualization of relational identification in learning relationships can be crucial for our understanding of alliance asymmetry. Moreover, by focusing on the smaller firm of an asymmetric alliance, our study probes how small firm-large firm interaction might be driven towards conducting exploratory and exploitative learning.

\section{Managerial implications}

One obvious managerial implication is for alliance managers to focus special attention on the strengthening of identification when motivating small partner firms to conduct learning. While alliance partnership provides firms with access to external knowledge, we have shown that the extent to which a small firm conducts exploratory and exploitative learning is significantly dependent on its identification with the partnership. Alliance managers should thus spend time and energy improving the state of small firm's relational identification. Or they may consider rejecting collaboration offers with small firms that do not identify with the partnership, especially when they aim to obtain benefits from the small firms' exploration. As our study has suggested that the strength of relational identification is determined by the ways large partners are involved in the small partner's activities, alliance managers should encourage extensive joint activity participation in the collaboration.

Managers of small firms also need to understand that the learning benefits of partnership with large firms cannot be fully realized if they fail to strengthen their identification with such a partnership. In order to do so, they should be involved in joint actions with their large partners. Moreover, different types of joint actions may affect knowledge exploration and exploitation in different ways. Our findings have indicated that joint sensemaking and joint problem-solving with a large partner may have either a direct or an indirect impact on a small firm's knowledge exploitation versus exploration. 
To realize the benefit of alliance partnerships in driving ambidextrous learning, managers of small firms should formulate appropriate strategies for engaging in joint activities. Such strategies cannot be a reaction to management needs, but ex-ante plans for certain learning objectives (i.e., exploration versus exploitation).

\section{Limitations and future research}

The contributions of this study should be considered in the light of its limitations. First, our evaluation of joint problem-solving and joint sensemaking was based on the responses of small firms. As our questionnaires were filled in by one party in each asymmetric relationship, we were unable to obtain an evaluation of joint problem-solving and joint sensemaking from both sides of each relationship. Consequently, we may have failed to capture the whole landscape of joint actions. Future research can aim to overcome this limitation.

Second, while we introduced joint problem-solving and joint sensemaking as indicators of joint actions, there are other types of joint actions that may affect a small firm's relational identification and knowledge exploration. Partnership interactions consist of a series of actions, ranging from the strategic to the operational, and from process to technological activities (e.g., Aggarwal, Siggelkow, and Singh, 2011; Heide and John, 1990; McEvily and Marcus, 2005). Different types of joint actions may influence a small firm's relational identification and knowledge exploration in diverse ways. For example, joint actions in R\&D affairs could be associated with more risks than joint actions around supply-chain issues, and thus more difficulties for strengthening a small firm's relational identification. Future research could deepen our understanding of the relationship between joint actions and small-firm relational identification by introducing a more detailed categorization of joint actions.

Third, future research can introduce different risk and cost profiles of joint actions. Since joint actions require a commitment of knowledge and investments, it is likely that the risk and cost elements in such interactions exert detrimental impacts on relational identification. One of the challenges in such contexts refers to the protection of intellectual property rights. Because joint actions facilitate a large firm's knowledge appropriation in collaboration, the small firm may pay 
special attention to its intellectual property rights (e.g., Freel and Robson, 2017; Katila et al., 2008). This may reversely affect the small firm's attitude toward joint actions. A next step would be to link the protection of intellectual property rights with the process of strengthening relational identification, and to identify how such mechanisms affect knowledge exploration and exploitation.

\section{REFERENCES}

Aggarwal VA, Siggelkow N and Singh H (2011) Governing collaborative activity: interdependence and the impact of coordination and exploration. Strategic Management Journal 32: 705-730.

Ahearne M, Bhattacharya CB and Gruen TW (2005) Antecedents and consequences of customer-company identification: expanding the role of relationship marketing. Journal of Applied Psychology 90: 574-585.

Anderson JC and Gerbing DW (1988) Structural equation modeling in practice: a review and recommended two step approach. Psychological Bulletin 103: 411-423.

Arranz N, Arroyabe MF and Arroyabe JCF (2016) Alliance-building process as inhibiting factor for SME international alliances. British Journal of Management 27: 497-515.

Ashforth BE and Mael F (1989) Social identity theory and the organization. Academy of Management Review 14: $20-39$.

Auh S, Bell SJ, McLeod CS and Shih E (2007). Co-production and customer loyalty in financial services. Journal of Retailing 83: 359-370.

Baron RM and Kenny DA (1986) The moderator-mediator variable distinction in social psychological research: Conceptual, strategic, and statistical considerations. Journal of Personality \& Social Psychology 51: $1173-1182$.

Benitez J, Castillo A, Llorens J and Braojos J (2018) IT-enabled knowledge ambidexterity and innovation performance in small U.S. firms: The moderator role of social media capability. Information \& Management 55: 131-143.

Benner MJ and Tushman ML (2003) Exploitation, exploration and process management: the productivity dilemma revisited. Academy of Management Review 28: 238-256.

Bhattacharya CB and Sen S (2003) Consumer-company identification: a framework for understanding consumers' relationships with companies. Journal of Marketing 67: 76-88.

Bishop JW and Scott KD (2000) An examination of organizational and team commitment in a self-directed team environment. Journal of Applied Psychology 85: 439-450. 
Brewer MB and Gardner W (1996) Who is this "we": Levels of collective identity and self-representations. Journal of Personality and Social Psychology 71: 83-93.

Brickson SL (2007) Organizational identity orientation: The genesis of the role of the firm and distinct Forms of social value. Academy of Management Review 32: 864-888.

Brunner-Sperdin A, Scholl-Grissemann US and Stokburger-Sauer NE (2014) The relevance of holistic website perception. How sense-making and exploration cues guide consumers' emotions and behaviors. Journal of Business Research 67: 2515-2522.

Carlson DS and Kacmar KM (2000) Work-family conflict in the organization: Do life role values make a difference? Journal of Management 26: 1031-1054.

Choi S and McNamara G (2018) Repeating a familiar pattern in a new way: The effect of exploitation and exploration on knowledge leverage behaviors in technology acquisitions. Strategic Management Journal 39: $356-378$.

Claro DP, Hagelaar G and Omta O (2003) The determinants of relational governance and performance: how to manage business relationship? Industrial Marketing Management 32: 703-716.

Corsten D, Gruen T and Peyinghaus M (2011) The effects of supplier-to-buyer identification on operational performance-An empirical investigation of inter-organizational identification in automotive relationships. Journal of Operations Management 29: 549-560

Cullen JB, Johnson JL and Sakano T (2000) Success through commitment and trust: the soft side of strategic alliance management. Journal of World Business 35: 223-240.

Danneels E (2002) The dynamics of product innovation and firm competences. Strategic Management Journal 23: $1095-1121$.

Dyer JH (1997) Effective interim collaboration: how firms minimize transaction costs and maximise transaction value. Strategic Management Journal 18: 535-556.

Dyer JH and Nobeoka K (2000) Creating and managing a high-performance knowledge-sharing network: The Toyota case. Strategic Management Journal 21: 345-367.

Dyer JH and Hatch NW (2004) Using supplier networks to learn faster. Sloan Management Review 45: 57-63. Dutta DK and Hora M (2017) From invention success to commercialization success: Technology ventures and the benefits of upstream and downstream supply-chain alliances. Journal of Small Business Management 55: $216-235$

Ellemers N, Kortekaas P and Ouwerkerk JW (1999) Self-categorization, commitment to the group and group 
self-esteem as related but distinct aspects of social identity. European Journal of Social Psychology 29: $371-389$.

Ellis N and Ybema S (2010) Marketing identities: Shifting circles of identification in inter-organizational relationships. Organization Studies 31: 279-305.

Flatten TC, Greve GI and Brettel M (2011) Absorptive capacity and firm performance in SMEs: The mediating influence of strategic alliances. European Management Review 8: 137-152.

Ford JK, MacCallum RC and Tait M (1986) The application of exploratory factor analysis in applied psychology: A critical review and analysis. Personnel Psychology 39: 291-314.

Frazier GL and Rody RC (1991) The use of influence strategies in interfirm relationships in industrial product channels. Journal of Marketing 55: 52-69.

Freel M and Robson PJ (2017) Appropriation strategies and open innovation in SMEs. International Small Business Journal 35: 578-596.

Fugate BS, Stank TP and Mentzer JT (2009) Linking improved knowledge management to operational and organizational performance. Journal of Operations Management 27: 247-264.

Füller J, Matzler K and Hoppe M (2008) Brand community members as a source of innovation. Journal of Product Innovation Management 25: 608-619.

Gaski JF (1984) The theory of power and conflict in channels of distribution. Journal of Marketing 48: 9-29.

Gawer A and Cusumano MA (2002) Platform leadership: how Intel, Microsoft and Cisco drive industry innovation. Boston, Masschusetts, Publisher: Harvard Business School Press.

Gawer A and Phillips N (2013) Institutional work as logics shift: the case of Intel's transformation to platform leader. Organization Studies 34: 1035-1071.

Gulati R (1998) Alliances and networks. Strategic Management Journal 19: 293-317.

Hagedoorn J, Lokshin B and Malo S (2018). Alliances and the innovation performance of corporate and public research spin-off firms. Small Business Economics 50: 763-781.

Handley K, Sturdy A, Fincham R and Clark T (2006) Within and beyond communities of practice: Making sense of learning through participation, identity and practice. Journal of Management Studies 43: 641-653.

Hashai N (2018) Focusing the high-technology firm: How outsourcing affects technological knowledge exploration. Journal of Management 44: 1736-1765.

He ZL and Wong PK (2004) Exploration vs. exploitation: An empirical test of the ambidexterity hypothesis. Organization Science 15: 481-494. 
Heide J and John G (1990) Alliances in industrial purchasing: the determinants of joint action in buyer-supplier relationships. Journal of Marketing Research 27: 24-36.

Hogg MA, van Knippenberg D and Rast DE (2012) Intergroup leadership in organizations: leading across group and organizational boundaries. Academy of Management Review 37: 232-255.

Hult GTM, Ketchen DJ and Slater SF (2004) Information processing, knowledge development and strategic supply chain performance. Academy of Management Journal 47: 241-253.

Ireland RD and Webb JW (2007) A multi-theoretic perspective on trust and power in strategic supply chains. Journal of Operations Management 25: 482-497.

Kalaignanam K, Shankar V and Varadarajan R (2007) Asymmetric new product development alliances: Win-win or win-lose partnerships? Management Science 53: 357-374.

Kale P, Singh H and Perlmutter H (2000) Learning and protection of proprietary assets in strategic alliances: Building relational capital. Strategic Management Journal 21: 217-237.

Kamuriwo DS, Baden-Fuller C and Zhang J (2017) Knowledge development approaches and breakthrough innovations in technology-based new firms. Journal of Product Innovation Management 34: 492-508.

Katila R, Rosenberg JD and Eisenhardt KM (2008) Swimming with sharks: technology ventures, defense mechanisms and corporate relationships. Administrative Science Quarterly 53: 295-332.

Kauppila O-P (2010) Creating ambidexterity by integrating and balancing structurally separate interorganizational partnerships. Strategic Organization 8: 283-312.

Kiss AN, Fernhaber S and McDougall-Covin PP (2018) Slack, innovation, and export intensity: Implications for small and medium-sized enterprises. Entrepreneurship Theory and Practice 42: 671-697.

Knoben J and Bakker RM (2019) The guppy and the whale: Relational pluralism and start-ups' expropriation dilemma in partnership formation. Journal of Business Venturing 34: 103-121.

Lane HW and Beamish PW (1990) Cross-cultural cooperative behavior in joint ventures in LCD's. Management International Review 30: 87-102.

Lave J and Wenger E (1991) Situated learning: Legitimate peripheral participation. Cambridge: Cambridge University Press.

Lerner J, Shane H and Tsai A (2003) Do equity financing cycles matter? Evidence from biotechnology alliances. Journal of Financial Economics 67: 411-446.

Levinthal DA and March JG (1993) The myopia of learning. Strategic Management Journal 14: 95-112.

Li D, Eden L, Hitt MA and Ireland RD (2008) Friends, acquaintances or strangers? Partner selection in R\&D 
alliances. Academy of Management Journal 51: 315-334.

Li JJ, Poppo L and Zhou KZ (2010) Relational mechanisms, formal contracts, and local knowledge acquisition by international subsidiaries. Strategic Management Journal 31: 349-370.

Li H and Zhang Y (2007) The role of managers' political networking and functional experience in new venture performance: evidence from China's transition economies. Strategic Management Journal 28: 791-804.

MacKinnon DP, Lockwood CM and Williams J (2004) Confidence limits for the indirect effect: Distribution of the product and resampling methods. Multivariate Behavioral Research 39: 99-128.

Maitlis S (2005) The social process of organizational sensemaking. Academy of Management Journal 48: $21-49$

Martin-Rios C and Erhardt N (2016) Small business activity and knowledge exchange in informal interfirm networks. International Small Business Journal 35: 285-305.

McEvily B and Marcus A (2005) Embedded ties and the acquisition of competitive capabilities. Strategic Management Journal 26: 1033-1055.

McGrath RG (2001) Exploratory learning, innovative capacity, and managerial oversight. Academy of Management Journal 44: 118-131.

McKelvie A, Brattström A and Wennberg K. (2017) How young firms achieve growth: reconciling the roles of growth motivation and innovative activities. Small Business Economics 49: 273-293.

Miller N (2002) Personalization and the promise of contact theory. Journal of Social Issues 58: 387-410.

Mishina Y, Block ES and Mannor MJ (2012) The path dependence of organizational reputation: how social judgment influences assessments of capability and character. Strategic Management Journal 33: 459-477.

Mitchell RK, Agle BR and Wood DJ (1997) Toward a theory of stakeholder identification and salience:

Defining the principle of who and what really counts. Academy of Management Review 22: 853-886.

Muthusamy SK and White MA (2005) Learning and knowledge transfer in strategic alliances: A social exchange view. Organization Studies 26: 415-441.

Ofek E and Sarvary M (2003) R\&D, Marketing, and the Success of Next-Generation Products. Marketing Science 22: 355-370.

Oliver C (1991) Strategic responses to institutional pressures. Academy of Management Review 16: 145-179.

Ozer M and Zhang W (2015) The effects of geographic and network ties on exploitative and exploratory product innovation. Strategic Management Journal 36: 1105-1114.

Parent MM and Deephouse DL (2007) A case study of stakeholder identification and prioritization by managers. 


\section{Journal of Business Ethics 75: 1-23.}

Perrons RK (2009) The open kimono: How Intel balances trust and power to maintain platform leadership. Research Policy 38: 1300-1312.

Peteraf M and Shanley M (1997) Getting to know you: A theory of strategic group identity. Strategic Management Journal 18: 165-186.

Podsakoff PM, MacKenzie SB, Lee JY and Podsakoff NP (2003) Common method biases in behavioral research: a critical review of the literature and recommended remedies. Journal of Applied Psychology 88: 879-903.

Podsakoff PM and Organ DW (1986) Self reports in organizational research: problems and prospects. Journal of Management 12: 531-544.

Preacher KJ and Hayes AF (2008) Asymptotic and resampling strategies for assessing and comparing indirect effects in multiple mediator models. Behavior Research Methods 40: 879-891.

Ragatz GL, Handfield RB and Scannell TV (1997) Success factors for integrating suppliers into new product development. Journal of Product Innovation Management 14: 190-202.

Revilla E and Villena VH (2012) Knowledge integration taxonomy in buyer-supplier relationships: Trade-offs between efficiency and innovation. International Journal of Production Economics 140: 854-864.

Rodan S and Galunic C (2004) More than network structure: how knowledge heterogeneity influences managerial performance and innovativeness. Strategic Management Journal 25: 541-562.

Rothaermel FT (2001) Complementary assets, strategic alliances, and the incumbent's advantage: an empirical study of industry and firm effects in the biopharmaceutical industry. Research Policy 30: 1235-1251.

Rothaermel FT and Deeds DL (2004) Exploration and exploitation alliances in biotechnology - a system of new product development. Strategic Management Journal 25: 201-221.

Rowley TJ (1997) Moving beyond dyadic ties: A network theory of stakeholder influences. Academy of Management Review 22: 887-910.

Sammarra A and Biggiero L (2001) Identity and identification in industrial districts. Journal of Management and Governance 5: 61-82.

Scott SG and Lane VR (2000) A stakeholder approach to organizational identity. Academy of Management Review 25: 43-62.

Seidl D and Werle F (2018) Inter-organizational sensemaking in the face of strategic meta-problems: Requisite variety and dynamics of participation. Strategic Management Journal 39: 830-858.

Shaw E, Wilson $\mathrm{J}$ and Pret $\mathrm{T}$ (2017) The process of embedding a small firm in its industrial context 
International Small Business Journal 35: 219-243.

Shrout PE and Bolger N (2002) Mediation in experimental and nonexperimental studies: New procedures and recommendations. Psychological Methods 7: 422-445.

Skarp F and Gadde L (2008) Problem solving in the upgrading of product offerings — A case study from the steel industry. Industrial Marketing Management 37: 725-737.

Sluss DM and Ashforth BE (2007) Relational identity and identification: Defining ourselves through work relationships. Academy of Management Review 32: 9-32.

Sluss DM and Ashforth BE (2008) How relational and organizational identification converge: Processes and conditions. Organization Science 19: 807-823.

Smircich L and Stubbart C (1985) Strategic management in an enacted world. Academy of Management Review 10: $724-736$.

Sobel ME (1982) Asymptotic confidence intervals for indirect effects in structural equation models. In S. Leinhardt (Ed.), Sociological Methodology, 1982 (pp. 290-312). Washington DC: American Sociological Association.

Stettner U and Lavie D (2014) Ambidexterity under scrutiny: exploration and exploitation via internal organization, alliances, and acquisitions. Strategic Management Journal 25: 1903-1929.

Stuart TE (2000) Interorganizational alliances and the performance of firms: a study of growth and innovation. Strategic Management Journal 21: 791-811.

Stuart TE, Hoang H and Hybels RC (1999) Interorganizational endorsements and the performance of entrepreneurial ventures. Administrative Science Quarterly 44: 315-349.

Subramanian AM, Bo W and Kah-Hin C (2018) The role of knowledge base homogeneity in learning from strategic alliances. Research Policy 47: 158-168.

Thorgren S, Wincent J and Örtqvist D (2012) Unleashing synergies in strategic networks of SMEs: The influence of partner fit on corporate entrepreneurship. International Small Business Journal 30(5): 453-471

Turner JC (1975) Social comparison and social identity: Some prospects for intergroup behaviour. European Journal of Social Psychology 5: 5-34.

Van de Ven A and Walker G (1984) The dynamics of interorganizational coordination. Administrative Science Quarterly 29: 598-621.

Van der Vegt GS and Bunderson JS (2005) Learning and performance in multidisciplinary teams: the importance of collective team identification. Academy of Management Journal 48: 532-547. 
Van Gils A and Zwart PS (2009) Alliance formation motives in SMEs. International Small Business Journal 27: $5-37$.

Volery T, Mueller S and von Siemens B (2015) Entrepreneur ambidexterity: A study of entrepreneur behaviours and competencies in growth-oriented small and medium-sized enterprises. International Small Business Journal 33: 109-129.

Wang SL, Luo Y, Maksimov V, Sun J and Celly N (2019) Achieving temporal ambidexterity in new ventures. Journal of Management Studies Article in advance: 1-35.

Wang M-C, Chen P-C and Fang S-C (2018) A critical view of knowledge networks and innovation performance: The mediation role of firms' knowledge integration capability. Journal of Business Research 88: 222-233.

Wassmer U and Dussauge P (2011) Value creation in alliance portfolios: The benefits and costs of network resource interdependencies. European Management Review 8: 47-64.

Weick KE (1993) The collapse of sensemaking in organizations: The Mann Gulch disaster. Administrative Science Quarterly 38: 628-652.

Woldesenbet K, Ram M and Jones T (2011) Supplying large firms: The role of entrepreneurial and dynamic capabilities in small businesses. International Small Business Journal 30: 493-512.

Yam CM, Lo W, Tang PY and Lau KW (2011) Analysis of sources of innovation, technological innovation capabilities, and performance: An empirical study of Hong Kong manufacturing industries. Research Policy 40: 391-402.

Yang H, Zheng Y and Zhao X (2014) Exploration or exploitation? Small firm's alliance strategies with large firms. Strategic Management Journal, 35: 146-157.

Zeng M and Chen XP (2003) Achieving cooperation in multiparty alliances: a social dilemma approach to partnership management. Academy of Management Review 28: 587-605.

Zhao ZJ and Chadwick C (2014) What we will do versus what we can do: The relative effects of unit-level NPD motivation and capability. Strategic Management Journal 35: 1867-1880.

Zhou KZ and Li CB (2012) How knowledge affects radical innovation: knowledge base, market knowledge acquisition, and internal knowledge sharing. Strategic Management Journal 33: 1090-1102. 
Table 1 Descriptive statistics and correlations

\begin{tabular}{|c|c|c|c|c|c|c|c|c|c|c|c|c|c|c|}
\hline & Mean & S.D. & 1 & 2 & 3 & 4 & 5 & 6 & 7 & 8 & 9 & 10 & 11 & 12 \\
\hline 1.Firm age & 2.863 & 1.015 & & & & & & & & & & & & \\
\hline 2.Firm size & 2.668 & 0.817 & 0.528 & & & & & & & & & & & \\
\hline 3.Industry type & 0.590 & 0.494 & 0.102 & 0.098 & & & & & & & & & & \\
\hline 4.Duration & 2.605 & 1.096 & 0.440 & 0.351 & 0.022 & & & & & & & & & \\
\hline 5.R\&D competence & 5.098 & 1.077 & -0.115 & 0.161 & -0.007 & -0.018 & & & & & & & & \\
\hline 6.Competition intensity & 4.320 & 1.194 & 0.019 & 0.017 & 0.041 & -0.061 & -0.078 & & & & & & & \\
\hline 7.Equity crossholding & 0.230 & 0.421 & 0.085 & -0.131 & -0.059 & 0.049 & -0.172 & 0.006 & & & & & & \\
\hline 8.Relationship substitutability & 4.171 & 1.762 & 0.123 & 0.016 & 0.144 & 0.144 & 0.000 & 0.119 & 0.125 & & & & & \\
\hline 9.Joint sensemaking & 5.250 & 0.986 & -0.224 & -0.074 & -0.024 & 0.016 & 0.205 & 0.057 & -0.096 & -0.052 & & & & \\
\hline 10.Joint problem-solving & 4.594 & 1.020 & -0.096 & -0.039 & -0.002 & -0.023 & 0.211 & 0.070 & -0.003 & 0.059 & 0.479 & & & \\
\hline 11.Relational identification & 4.483 & 1.059 & -0.014 & -0.012 & 0.085 & 0.068 & .0136 & -0.090 & -0.000 & 0.261 & 0.272 & 0.381 & & \\
\hline 12.Exploration & 5.366 & 0.869 & -0.161 & 0.014 & -0.050 & 0.015 & 0.414 & -0.082 & -0.100 & -0.155 & 0.277 & 0.165 & 0.207 & \\
\hline 13.Exploitation & 5.515 & 0.937 & -0.102 & 0.110 & -0.019 & 0.083 & 0.541 & -0.072 & -0.058 & -0.027 & 0.286 & 0.205 & 0.205 & 0.571 \\
\hline
\end{tabular}

Correlations equal to or greater than $|0.119|$ are significant at 0.10 level. 
Table 2 Regression results for relational identification

\begin{tabular}{llll}
\hline & \multicolumn{3}{c}{$\begin{array}{c}\text { Dependent Variable: Relational } \\
\text { identification }\end{array}$} \\
\cline { 2 - 4 } & Model 1 & Model 2 & Model 3 \\
\hline Firm age & -.038 & .033 & -.013 \\
Firm size & $.093)$ & $(.087)$ & $(.085)$ \\
& -.056 & -.042 & -.034 \\
Industry type & $(.105)$ & $(.102)$ & $(.110)$ \\
& .124 & .123 & .124 \\
Duration & $(.153)$ & $(.148)$ & $(.145)$ \\
& .054 & .012 & .046 \\
R\&D competence & $(.065)$ & $(.064)$ & $(.061)$ \\
& $.127^{*}$ & .075 & .047 \\
Competition intensity & $(.070)$ & $(.069)$ & $(.067)$ \\
& -.097 & -.120 & $-.124^{*}$ \\
Equity crossholding & $(.076)$ & $(.073)$ & $(.070)$ \\
& -.031 & .004 & -.056 \\
Relationship & $(.164)$ & $(.156)$ & $(.156)$ \\
substitutability & $.159^{* * *}$ & $.167^{* * *}$ & $.148^{* * *}$ \\
Joint sensemaking & $(.048)$ & $(.046)$ & $(.045)$ \\
Joint problem-solving & & $.301^{* * *}$ & \\
& & $(.073)$ & $.379^{* * *}$ \\
F value & & & $(.068)$ \\
Adjusted R 2 & $2.69^{* * *}$ & $4.76^{* * *}$ & $6.70^{* * *}$ \\
\hline
\end{tabular}

Notes: Robust standard errors in parentheses

${ }^{* * *} \mathrm{p}<0.01{ }^{* *} \mathrm{p}<0.05{ }^{*} \mathrm{p}<0.1$ (sample size=205) (two-tailed tests) 
Table 3 Regression results for knowledge exploration and exploitation

\begin{tabular}{|c|c|c|c|c|c|c|c|c|c|c|c|c|}
\hline & \multicolumn{6}{|c|}{ Dependent variable: knowledge exploration } & \multicolumn{6}{|c|}{ Dependent variable: knowledge exploitation } \\
\hline & Model 4 & Model 5 & Model 6 & Model 7 & Model 8 & Model 9 & Model 10 & Model 11 & Model 12 & Model 13 & Model 14 & Model 15 \\
\hline Firm age & $\begin{array}{c}-.115^{* * *} \\
(.075)\end{array}$ & $\begin{array}{l}.079 \\
(.074)\end{array}$ & $\begin{array}{l}-.110 \\
(.076)\end{array}$ & $\begin{array}{l}-.108 \\
(.074)\end{array}$ & $\begin{array}{l}-.083 \\
(.074)\end{array}$ & $\begin{array}{l}-.108 \\
(.075)\end{array}$ & $\begin{array}{l}-.118 \\
(.075)\end{array}$ & $\begin{array}{l}-.079 \\
(.076)\end{array}$ & $\begin{array}{l}-.112 \\
(.076)\end{array}$ & $\begin{array}{l}-.113 \\
(.075)\end{array}$ & $\begin{array}{l}.082 \\
(.076)\end{array}$ & $\begin{array}{l}.110 \\
(.076)\end{array}$ \\
\hline Firm size & $\begin{array}{l}-.015 \\
(.080)\end{array}$ & $\begin{array}{l}-.008 \\
(.078)\end{array}$ & $\begin{array}{l}-.011 \\
(.080)\end{array}$ & $\begin{array}{l}-.006 \\
(.080)\end{array}$ & $\begin{array}{l}-.002 \\
(.079)\end{array}$ & $\begin{array}{l}-.005 \\
(.080)\end{array}$ & $\begin{array}{c}.061 \\
(.090)\end{array}$ & $\begin{array}{c}.069 \\
(.089)\end{array}$ & $\begin{array}{l}.066 \\
(.090)\end{array}$ & $\begin{array}{l}.069 \\
(.092)\end{array}$ & $\begin{array}{c}.073 \\
(.090)\end{array}$ & $\begin{array}{c}.070 \\
(.091)\end{array}$ \\
\hline Industry type & $\begin{array}{l}-.023 \\
(.117)\end{array}$ & $\begin{array}{l}-.024 \\
(.115)\end{array}$ & $\begin{array}{l}-.023 \\
(.117)\end{array}$ & $\begin{array}{l}-.044 \\
(.112)\end{array}$ & $\begin{array}{l}-.041 \\
(.112)\end{array}$ & $\begin{array}{l}-.043 \\
(.112)\end{array}$ & $\begin{array}{l}-.003 \\
(.116)\end{array}$ & $\begin{array}{l}-.004 \\
(.114)\end{array}$ & $\begin{array}{l}-.003 \\
(.115)\end{array}$ & $\begin{array}{l}-.019 \\
(.116)\end{array}$ & $\begin{array}{l}-.015 \\
(.114)\end{array}$ & $\begin{array}{l}-.017 \\
(.115)\end{array}$ \\
\hline $\begin{array}{l}\mathrm{R} \& \mathrm{D} \\
\text { competence }\end{array}$ & $\begin{array}{l}.323^{* * *} \\
(.061)\end{array}$ & $\begin{array}{c}.297^{* * *} \\
(.063)\end{array}$ & $\begin{array}{c}.307^{* * *} \\
(.063)\end{array}$ & $\begin{array}{l}.302^{* * *} \\
(.063)\end{array}$ & $\begin{array}{c}.286^{* * *} \\
(.064)\end{array}$ & $\begin{array}{l}.300^{* * *} \\
(.063)\end{array}$ & $\begin{array}{l}.458^{* * *} \\
(.052)\end{array}$ & $\begin{array}{l}.431^{* * *} \\
(.054)\end{array}$ & $\begin{array}{l}.440^{* * *} \\
(.055)\end{array}$ & $\begin{array}{c}.442^{* * *} \\
(.053)\end{array}$ & $\begin{array}{c}.423^{* * *} \\
(.055)\end{array}$ & $\begin{array}{l}.434^{* * *} \\
(.055)\end{array}$ \\
\hline $\begin{array}{l}\text { Competition } \\
\text { intensity }\end{array}$ & $\begin{array}{l}-.017 \\
(.047)\end{array}$ & $\begin{array}{l}-.028 \\
(.046)\end{array}$ & $\begin{array}{l}-.022 \\
(.046)\end{array}$ & $\begin{array}{l}-.001 \\
(.046)\end{array}$ & $\begin{array}{l}-.012 \\
(.046)\end{array}$ & $\begin{array}{l}-.002 \\
(.047)\end{array}$ & $\begin{array}{l}-.014 \\
(.048)\end{array}$ & $\begin{array}{l}-.027 \\
(.047)\end{array}$ & $\begin{array}{l}-.020 \\
(.047)\end{array}$ & $\begin{array}{l}-.002 \\
(.048)\end{array}$ & $\begin{array}{l}-.015 \\
(.048)\end{array}$ & $\begin{array}{l}-.006 \\
(.048)\end{array}$ \\
\hline $\begin{array}{l}\text { Equity } \\
\text { crossholding }\end{array}$ & $\begin{array}{l}-.018 \\
(.139)\end{array}$ & $\begin{array}{l}.000 \\
.136)\end{array}$ & $\begin{array}{c}-.023 \\
(.139)\end{array}$ & $\begin{array}{l}-.013 \\
(.133)\end{array}$ & $\begin{array}{l}.000 \\
-.000 \\
(.133)\end{array}$ & $\begin{array}{l}-.013 \\
(.135)\end{array}$ & $\begin{array}{l}.107 \\
(.146)\end{array}$ & $\begin{array}{l}.127 \\
(.145)\end{array}$ & $\begin{array}{l}.101 \\
(.148)\end{array}$ & $\begin{array}{l}.111 \\
(.145)\end{array}$ & $\begin{array}{l}.126 \\
.144)\end{array}$ & $\begin{array}{l}.108 \\
.147)\end{array}$ \\
\hline $\begin{array}{l}\text { Relationship } \\
\text { substitutability } \\
\text { Joint } \\
\text { sensemaking }\end{array}$ & $\begin{array}{c}-.073^{* *} \\
(.034)\end{array}$ & $\begin{array}{c}-.069^{* *} \\
(.034) \\
.153^{* * *} \\
(.067)\end{array}$ & $\begin{array}{c}-.075^{* *} \\
(.034)\end{array}$ & $\begin{array}{c}-.099 * * * \\
(.036)\end{array}$ & $\begin{array}{c}-.092^{* *} \\
(.036) \\
.112^{*} \\
(.059)\end{array}$ & $\begin{array}{c}-.099 * * * \\
(.036)\end{array}$ & $\begin{array}{l}-.019 \\
(.031)\end{array}$ & $\begin{array}{l}-.014 \\
(.030) \\
.165^{* * *} \\
(.063)\end{array}$ & $\begin{array}{l}-.021 \\
(.031)\end{array}$ & $\begin{array}{l}-.039 \\
(.034)\end{array}$ & $\begin{array}{l}-.030 \\
(.034) \\
.137^{* *} \\
(.064)\end{array}$ & $\begin{array}{l}-.038 \\
(.034)\end{array}$ \\
\hline $\begin{array}{l}\text { Joint } \\
\text { problem-solvin } \\
\mathrm{g}\end{array}$ & & & $\begin{array}{l}.073 \\
(.058)\end{array}$ & & & $\begin{array}{l}.011 \\
(.060)\end{array}$ & & & $\begin{array}{c}.089 \\
(.062)\end{array}$ & & & $\begin{array}{l}.046 \\
(.064)\end{array}$ \\
\hline $\begin{array}{l}\text { Relational } \\
\text { identification }\end{array}$ & & & & $\begin{array}{c}.166^{* * *} \\
(.060)\end{array}$ & $\begin{array}{l}.137^{* *} \\
(.063)\end{array}$ & $\begin{array}{l}.162^{* *} \\
(.064)\end{array}$ & & & & $\begin{array}{l}.130^{* *} \\
(.061)\end{array}$ & $\begin{array}{c}.094 \\
(.063)\end{array}$ & $\begin{array}{l}.113^{* *} \\
(.064)\end{array}$ \\
\hline F value & $5.23^{* *}$ & $6.19^{* * *}$ & $5.04^{* * *}$ & $6.74^{* * *}$ & $6.89 * * *$ & $6.11^{* * *}$ & $13.71^{* *}$ & $12.99^{* * *}$ & $12.15^{* * *}$ & $12.51^{* * *}$ & $11.90^{* * *}$ & $11.25^{* * *}$ \\
\hline Adjusted $\mathrm{R}^{2}$ & .183 & .207 & .186 & .217 & .227 & .214 & .286 & .311 & .292 & .303 & .317 & .301 \\
\hline
\end{tabular}

${ }^{* * *} \mathrm{p}<0.01{ }^{* *} \mathrm{p}<0.05{ }^{*} \mathrm{p}<0.1$ (sample size $=205$ ) (two-tailed tests) 
Table 4 Bootstrapping test for indirect effect

\begin{tabular}{cccccc}
\hline \multirow{2}{*}{$\begin{array}{c}\text { Dependent } \\
\text { variable }\end{array}$} & \multirow{2}{*}{$\begin{array}{c}\text { Independent } \\
\text { variable }\end{array}$} & Effect & Bootstrap & \multicolumn{2}{c}{ Confidence interval } \\
\cline { 5 - 6 } Exploration & & & standard error & Lower limit & Upper limit \\
& Joint sensemaking & 0.0341 & 0.0189 & 0.0015 & 0.0768 \\
& Joint problem-solving & 0.0547 & 0.0254 & 0.0079 & 0.1096 \\
\hline Exploitation & Joint sensemaking & 0.0355 & 0.0210 & -0.0001 & 0.0852 \\
& Joint problem-solving & 0.0519 & 0.0289 & 0.0019 & 0.1173 \\
\hline
\end{tabular}

Note: Relational identification as mediating variable.

Figure 1 Results of bootstrapping test

\section{$1 a \quad$ IV: Joint sensemaking DV: Exploration}

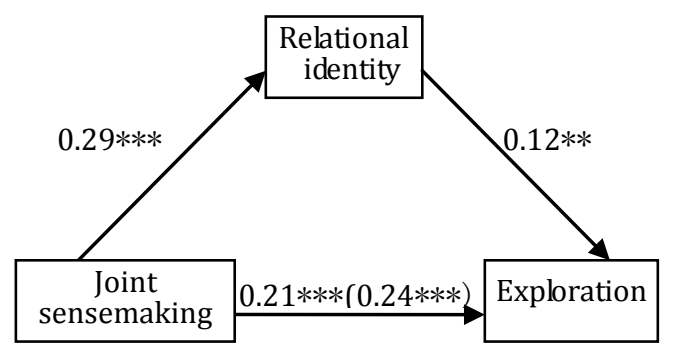

1c IV: Joint sensemaking DV: Exploitation

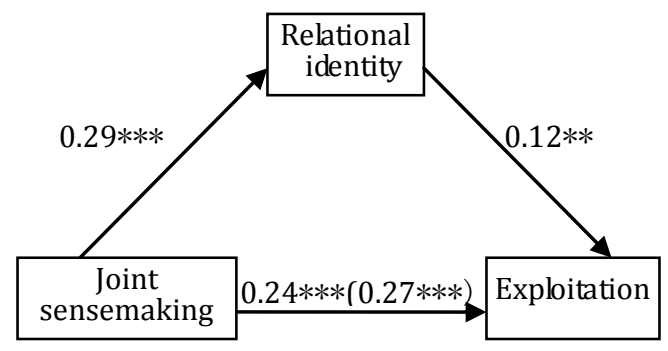

Notes: ${ }^{* * *} \mathrm{p}<0.01 ;{ }^{* *} \mathrm{p}<0.05 ;^{*} \mathrm{p}<0.1$.
$1 b \quad$ IV: Joint problem-solving DV: Exploration

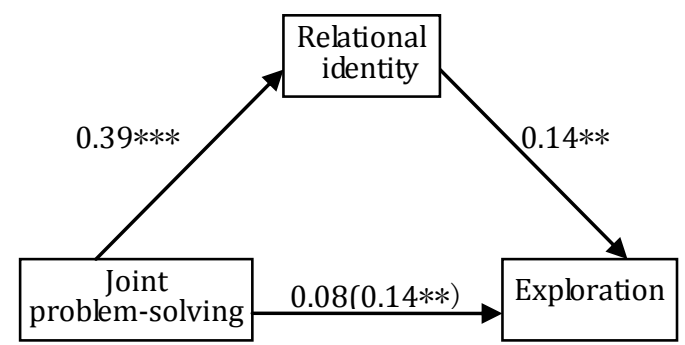

1d IV: Joint problem-solving DV: Exploitation

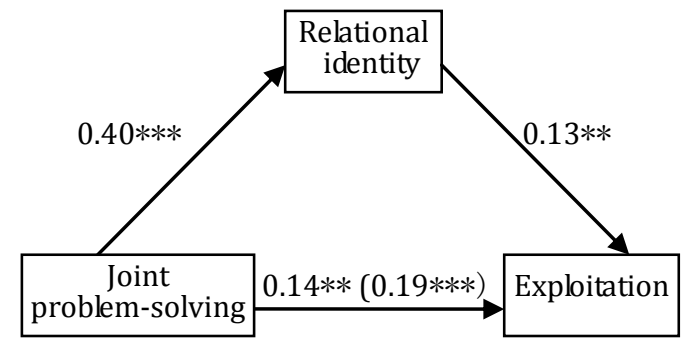

